
\title{
3 Research Square \\ Plasma Disinfection: Cold Atmospheric Pressure Plasma Attenuates SARS-CoV-2 Spike Protein Binding to ACE2 Protein and the RNA
}

\section{Rakesh Ruchel Khanikar}

Institute of Advanced Study in Science and Technology

Monalisa Kalita

Institute of Advanced Study in Science and Technology

Parismita Kalita

Institute of Advanced Study in Science and Technology

Bhaswati Kashyap

Institute of Advanced Study in Science and Technology

\section{Santanu Das}

Institute of Advanced Study in Science and Technology

Mojibur R. Khan

Institute of Advanced Study in Science and Technology

Heremba Bailung

Institute of Advanced Study in Science and Technology

Kamatchi Sankaranarayanan ( $\sim$ kamatchis@iasst.gov.in )

Institute of Advanced Study in Science and Technology

\section{Research Article}

Keywords: Cold Atmospheric Plasma, Spike protein, ACE2 protein, SARS-VoV-2 virus, Plasma medicine

Posted Date: November 29th, 2021

DOI: https://doi.org/10.21203/rs.3.rs-1065088/v1

License: (c) (i) This work is licensed under a Creative Commons Attribution 4.0 International License. Read Full License 


\section{Abstract}

Cold atmospheric pressure (CAP) plasma has a profound effect on protein-protein interactions. In this work, we have highlighted the deactivation of the severe acute respiratory syndrome coronavirus 2 (SARSCoV-2) Spike protein by CAP plasma treatment. Complete deactivation of spike protein binding to the human ACE2 protein was observed within exposure time of 5 minutes and which is correlated to the higher concentration of hydrogen peroxide formation due to the interaction with the reactive oxygen species present in the plasma. On the other hand, it is established that CAP plasma is also capable of degrading RNA of SARS-CoV-2 virus which is also linked to hydrogen peroxide concentration. Results of this work could be useful in designing plasma-based disinfection systems over those based on environmentally hazardous chemicals-based disinfections.

\section{Introduction}

The novel coronavirus disease (Covid-19) is caused by severe acute respiratory syndrome coronavirus 2 (SARS-CoV-2) which is a positive sense single stranded RNA virus ${ }^{1}$. The genome of the virus is packed in an envelope comprising of three proteins namely, membrane, spike, and envelope proteins. It is reported that the sustained interactions in SARS-CoV-2 and the major infection spread is caused by the binding of spike protein with the human angiotensin converting enzyme 2 (hACE2) protein for the virus entry through the receptor binding domain (RBD) region ${ }^{2,3}$. The major cause of the spread is air-borne wherein the virus spreads through the respiratory droplets of infected patients. On entry into the nasal cavity, the spike protein of the virus binds to the ACE2 protein in the cell wall to make way for the virus entry ${ }^{4}$. The second wave has hit hard in most of the developing countries especially India (especially due to the delta variant of the SARS-CoV-2). With the rapid increase in the Covid-19 infections worldwide and deaths reaching 4.2 million as of August 2021 and it is therefore necessary to look for additional approaches to minimize the risk of SARS-CoV-2 transmission.

The interaction of cold atmospheric pressure (CAP) plasma with biological materials like living tissues, cells, bacteria, viruses is an emerging interdisciplinary field of research ${ }^{5-7}$. The CAP plasma contains various active species such as electrons, ions, reactive oxygen and nitrogen species (RONS) and UVphotons making it useful in biomedical field specially for deactivation of bacteria, fungi, spores and viruses ${ }^{8-11}$. CAP plasma has also been found effective for inactivation or modification of several proteins such as lysozyme ${ }^{12}$, myoglobin and haemoglobin ${ }^{13}$, NADPH oxidase (NOX) enzymes ${ }^{14}$ and RNAse ${ }^{15}$. Recently, few reports have shown that CAP plasma is effective in inactivation of SARS-CoV-2 virus ${ }^{16,17}$. Plasma activated water has been used to study the spike protein deactivation ${ }^{17}$, however, there is storage issue of activated water for a longer time.

SARS-CoV-2 virus remains stable as aerosols for longer periods of time and, to stop their spread, it is crucial to treat not only surfaces but also the air inside hospital/laboratory as well as living/office rooms. Traditional chemical disinfectants used in fogging have serious limitations due to its toxicity for human 
as well as material body. UV based disinfection can effectively deactivate the genetic material of the virus, however, has several associated issues with respect to affecting the human $\operatorname{skin}^{18}$. In view of environmental protection, novel environmentally friendly decontamination methods are a need of the hour. In this work, we explored the process of deactivation of the spike protein of the Covid-19 virus using cold atmospheric pressure plasma and its effect on the RNA of the virus.

\section{Materials And Methods}

SARS-CoV-2 (2019-nCoV) Spike (S1+S2 ECD-His Recombinant) protein, Anti-His tag HRP Antibody, human ACE2 protein (mFc Tag), TMB highly Sensitive HRP Substrate were purchased from Krishgen Biosystems, India and used without further purification. BSA, materials for buffer preparation were purchased from Sigma Aldrich, India. The reagents and buffers were prepared in Millipore water. RNA samples of SARS-CoV-2 virus extracted from samples of Covid-19 positive infected patients for Covid-19 testing (RT-PCR) were used. RNA extraction was done following standard protocols. Abundance of the viral RNA before and after CAP treatment was is evaluated in RT-PCR.

\section{Experimental Setup}

A cold atmospheric pressure plasma jet is used for the experiment. It is a modified form of the plasma jet described elsewhere with a modified electrode arrangement as shown in figure 1 (a) ${ }^{19}$. It consists of a glass tube with an inner diameter of $3 \mathrm{~mm}$ and an outer diameter of $7 \mathrm{~mm}$. The glass tube acts as the dielectric between the two electrodes. The glass tube and the live electrode assembly is fitted into a Teflon housing with a gas inlet. Plasma is generated in between the electrodes applying sinusoidal voltages $(2.5 \mathrm{KV}$ and $5.0 \mathrm{KV})$ at frequency $(30 \mathrm{KHz})$. Helium and a mixture of helium with compressed air have been used as the plasma forming gases. The gas flow has been measured using a variable area flowmeter (Cole Parmer). For He plasma, a helium gas flow of 1000-3000 sccm (standard cubic cm per minute) has been maintained to obtain a stable plasma. For He-air plasma, air flow of 50-200 sccm is mixed with helium. The plasma produced between the two electrodes comes out into the open air with the gas flow. The sample for plasma treatment is placed underneath (as shown in Figure 1) for different exposure times.

To investigate the various reactive species, present in the plasma, an emission spectrum of the plasma jet was obtained by using an optical emission spectrometer (Andor-SR-303i-A). The light emitted from the plasma was collected by an optical fiber fitted to the spectrometer equipped with three gratings consisting of 300,1200 and 2400 grooves $/ \mathrm{mm}$ and the slit width can be varied from 10-2500 $\mu \mathrm{m}$. In this experiment, a slit width of $50 \mu \mathrm{m}$ was used to achieve a fair resolution along with sufficient intensity. The survey spectrum was recorded using 1200 groves/mm grating in the wavelength range $250-900 \mathrm{~nm}$, whereas the $\mathrm{OH}$ emission is recorded using 2400 groves/mm grating in the wavelength range 306-310 $\mathrm{nm}$ to achieve high resolution. The spectrometer's wavelength calibration is performed using a standard NIST traceable calibration lamp (StellarNet Inc.). 


\section{Enzyme-linked immunosorbent assay (ELISA):}

The hACE2 protein was diluted with a coating buffer PBS (136.9 mM NaCl, $10.1 \mathrm{mM} \mathrm{Na}_{2} \mathrm{HPO}_{4}, 2.7 \mathrm{mM}$ $\mathrm{KCl}, 1.8 \mathrm{mM} \mathrm{KH}_{2} \mathrm{PO}_{4}, 0.2 \mu \mathrm{m}$ filtered) adjusted to $\mathrm{pH} 7.4$ to $2 \mu \mathrm{g} / \mathrm{ml}$ and added to the wells of 96-well plates $\left(100 \mu \mathrm{l}\right.$ per well). The plates were incubated at $4^{\circ} \mathrm{C}$ overnight and washed with water. Then, the wells were blocked with blocking buffer PBS-T (0.05\% Tween20 in PBS). containing $2 \%$ BSA for 60 min and washed. Next, a series of diluted SARS-CoV-2 (2019-nCoV) Spike protein from $20 \mu \mathrm{g} / \mathrm{ml}$ was prepared in the diluting buffer $(0.1 \%$ BSA in PBS-T) and incubated for $60 \mathrm{~min}$ in the well plates. To study the binding of spike proteins with hACE2, various concentrations of the spike protein viz., 2.5, 5, 10, 12.5 , $15,17.5,20 \mu \mathrm{g} / \mathrm{ml}$ were prepared and subjected to plasma treatment with two different feed gases $\mathrm{He}$ and He-air mixture. The wells were washed and incubated with $100 \mu \mathrm{l}$ of HRP detection antibody for 60 min. After washing, TMB substrate (Thermo Fisher) and $2 \mathrm{M} \mathrm{H}_{2} \mathrm{SO}_{4}$ were sequentially added to the wells. Then, the optical density was measured using a microplate reader (Thermo Scientific Varioskan Flash) at $450 \mathrm{~nm}$.

\section{Protein carbonyl content estimation}

The carbonyl content of the native and plasma treated spike protein was determined by 2,4dinitrophenylhydrazine (DNPH) assay ${ }^{20}$. Briefly, $200 \mu$ l protein samples were properly mixed with $800 \mu$ l of freshly prepared $0.1 \%$ 2,4-dinitrophenylhydrazine in $2.5 \mathrm{M} \mathrm{HCL}$ and incubated for $1.5 \mathrm{~h}$ at room temperature. Protein was precipitated by addition of $1000 \mu \mathrm{l}$ of $20 \%$ chilled trichloroacetic acid (TCA) followed by centrifugation at $4^{\circ} \mathrm{C}$. The pellet was then re-suspended and washed with chilled $10 \%$ TCA followed by washing twice with ice-cooled 50:50 (v/v) acetate and ethanol. Finally, the pellet was resuspended in $500 \mu \mathrm{l}$ of $6 \mathrm{M}$ guanidium chloride and absorption spectra were recorded at $370 \mathrm{~nm}$ with a molar absorptivity of $22000 \mathrm{M}^{-1} \mathrm{~cm}^{-1}$.

\section{RNA extraction}

RNA was extracted from nasopharyngeal and oropharyngeal swab samples using Qiagen QIAmp® Viral RNA Mini Kit (250) (Cat no. 52906; Qiagen India Pvt. Ltd, New Delhi) as per manufacturer's instruction. The swab samples were subjected to extraction with an elution volume of $50 \mu \mathrm{l}^{21}$. Extracted RNA was used for plasma treatment in a Bio Safety Level (BSL) - II facility and a $10 \mu$ of RNA sample from each treated and untreated samples was used in each SARS-CoV-2 detection assay.

SARS-CoV-2 detection assays. Written informed consents were taken for using the RNA samples. All the experiments were performed in an Indian Council of Medical Association (ICMR) approved biosafety level 2 (BSL-2) Covid-19 testing and research laboratory and by following the ethical and biosafety guidelines approved by IASST. Real-time RT-PCR assay was performed using the CoviPath ${ }^{\text {TM }}$ COVID-19 multiplex kit (Cat no. A50780; Thermofisher Scientific India Pvt. Ltd, Mumbai) as per manufacturer's instruction. RTPCR was performed on Agilent AriaMx real-time PCR system with the parameters: 2 mins at $25^{\circ} \mathrm{C}$ for incubation, $10 \mathrm{~min}$ at $53^{\circ} \mathrm{C}$ for reverse transcription and 2 mins at $95^{\circ} \mathrm{C}$ for activation followed by 40 
cycles of $3 \mathrm{~s}$ at $95^{\circ} \mathrm{C}$ and $30 \mathrm{~s}$ at $60^{\circ} \mathrm{C}^{22,23}$. The relative abundance of the viral RNA was calculated using $2^{-\triangle \Delta C T}$ method ${ }^{24,25}$. Abundance of the $N$ and ORF- genes were normalized to that of human RnaseP gene found in the swab samples and presented as the $\triangle \mathrm{CT}$ value (CT of target gene - CT of RnaseP). The relative abundance SARS-CoV-2 genes with respect to untreated controls were calculated as $2^{\square \Delta \triangle C T}$ where $\Delta \Delta C T=$ Control $(\Delta C T$ value $)-$ test $(\Delta C T$ value $)$.

\section{Determination of $\mathrm{OH}, \mathrm{H}_{2} \mathrm{O}_{2}$ and Nitrates through assays}

Hydrogen peroxide was determined using the assay kit by Sigma Aldrich (Catalog Number MAK165). Hydroxyl radicals were quantified by treating $20 \mathrm{mM}$ TA and comparing with a standard curve with hydroxyl-terephthalic acid. Nitrate/Nitrite was determined using the detection kit by Cayman Chemicals, USA.

\section{Results And Discussion}

Optical Diagnostics and Gas Temperature of the CAP Plasma

Figure 2 shows emission spectra obtained from the He and He-air plasma jet. The spectrum covers wavelength from $250 \mathrm{~nm}$ to $900 \mathrm{~nm}$. The spectral lines are identified using NIST atomic spectra database ${ }^{26}$ and reference ${ }^{27}$. The presence of various reactive species in the plasma jet can be seen from the spectrum, which includes molecular bands such as $\mathrm{OH}(A-X), \mathrm{N}_{2}(C-B), \mathrm{N}_{2}{ }^{+}(B-X)$ and atomic lines of helium and singlet oxygen etc. The presence of the molecular bands in the UV region of the emission spectrum indicates the high energetic UV emission from the plasma jet. In Figure 2 (a), the OES spectrum corresponding to the He plasma jet is shown where very weak emission lines from reactive oxygen and nitrogen species are seen (enlarged in the inset). In He-air plasma, the concentrations of reactive oxygen and nitrogen species are significantly increased. As a result, we observed a manifold increase in the RONS concentrations in the He-air plasma jet spectrum as shown in Figure 2 (b). Slight enhancement in UV radiation has also been observed. Some of the helium and hydrogen lines are barely visible in the Heair plasma jet spectrum. This is due to the overlapping of second order lines with the primary spectrum in Figure 2(b).

It is essential to know the gas temperature in a cold atmospheric plasma jet accurately specially for biological applications. One of the most popular gas temperature determination methods in low temperature humid atmospheric plasmas is from the measurement of rotational temperature from $\mathrm{OH}$ (A$\mathrm{X}$ ) emission band around $306-310 \mathrm{~nm}$. The rotational temperature can be determined from the comparison of the experimental spectrum with a simulated theoretical spectrum obtained from spectral simulation software like LIFBASE ${ }^{28}$ and SPECAIR ${ }^{29}$. The models assume Boltzmann distribution of rotational levels. The rotational temperature obtained from them is a good measure of gas temperature since the translational and rotational degrees of freedom remain in equilibrium in atmospheric pressure plasmas due to large number of collisions ${ }^{30,31}$. Figure $2 \mathrm{c}$ shows the best fit the $\mathrm{OH}$ molecular band between the recorded and the simulated spectrum from the software LIFBASE. The temperature of both 
He plasma jet and He-air plasma jet is found to be similar and estimated to be $330 \pm 20 \mathrm{~K}$ in the active region of plasma between the electrodes. While at the point of application, where the plasma plume comes out into open air, the gas temperature remains at room temperature. This can also be verified by the fact that the temperature of the sample remains unchanged after plasma treatment.

\section{ELISA characterization of the spike protein binding to the ACE2 proteins}

We performed the ELISA assay to characterize the binding of the ACE2 proteins to the Spike proteins before and after subjecting to the plasma exposure, and the results are presented in Figure 3. As mentioned earlier, CAP plasma was produced with two different feed gases, He and He-Air mixed gas with different discharge voltages $(2.5 \mathrm{kV}$ and $5 \mathrm{kV}, 30 \mathrm{KHz})$ and very short interaction times of $1 \mathrm{~min}$ and 2 min, which will be relevant for practical applications in large scale.

The binding of ACE2 protein to the spike protein is the most important factor behind the Covid -19 infection. To model such binding, in our study, we had taken various concentration of the spike protein from $2.5 \mu \mathrm{g} / \mathrm{ml}$ to $20 \mu \mathrm{g} / \mathrm{ml}$ (Figure 3 (a)). The binding efficiency of the various concentration of the spike proteins with ACE2 was evaluated after treating the protein to the plasma treatment. ACE2 binds to the spike protein almost with $\sim 100 \%$ efficiency (without plasma treatment). He plasma reduces the binding efficiency to about $70 \%$ and $60 \%$ respectively for the voltages of $2.5 \mathrm{KV}$ and $5 \mathrm{KV}$ within 1 min (Figure 3 (a)). The binding reduces to $40 \%$ with He-air plasma for same treatment time (1 min). Further increase in treatment time to 2 min reduces the binding efficiency more effectively and maximum reduction to 18\% has been estimated for He-air plasma treatment (Figure 3 (b)).

The superior effect of the He-air mixed feed gas plasma is attributed to the increase in the RONS production as observed from the optical emission spectra.

A similar treatment of the spike protein with the CAP plasma using both Helium and He-air mixed feed gas, for a particular concentration $10 \mu \mathrm{g} / \mathrm{ml}$ is presented in Figure 3 (c). Complete deactivation of the spike protein with the longer exposure time of 5 minutes is clearly evident for He-air plasma.

Further, the role of the reactive oxygen species (ROS) in the deactivation of the spike protein was determined using the DNPH assay. ROS can have major interactions with some amino acid residues such as Pro, Arg, Lys, and Thr leading to an oxidative cleavage of the protein backbone ${ }^{32,33}$. Protein-bound carbonyls are the most often used as markers to estimate protein oxidation. Earlier reports have shown that plasma treatment can modify or oxidize a variety of proteins, including horse radish peroxidase ${ }^{34}$ and such interactions can be tuned by adjusting the RONS ${ }^{35}$. These protein-bound carbonyls for the plasma treated spike proteins increased from a $2.1 \%$ for the control to $17.2 \%$ and $36.1 \%$ for the He and He-air mixed plasma for the 2 min plasma exposure time. The various modifications of the protein backbone due to the increased carbonyl content in the protein could be majorly responsible for the deactivation of the protein. 
Additionally, we performed RT-PCR analysis of the extracted RNA after plasma treatment. The relative abundance of the nucleocapsid protein encoding $\mathrm{N}$-gene and the open reading frame (ORF1ab) gene of the plasma treated samples were compared with the control and presented in Figure 4. The N-gene encodes the structural proteins in SARS-CoV-2, whereas the ORF gene encodes the nonstructural proteins 36. It is reported that by detecting the sole $\mathrm{N}$-gene, a positive rate similar to that of detecting both $\mathrm{N}$-gene and ORF1ab gene can be obtained ${ }^{37}$. From Figure 4, we observed that the effects of the $\mathrm{He}$ and He-air plasma were different on the abundance of the N-gene and ORF-gene. Treatment with He plasma caused increase in the relative abundance of both the genes with respect to the untreated controls $(239 \%$ for ORF1ab gene and $442 \%$ for $\mathrm{N}$-gene; $p<0.05$ ). On the other hand, treatment with He-air plasma caused a significant decrease in the abundance of the both the genes (23\% for ORF1ab gene and $35 \%$ for N-gene; $p<0.05)$. This could be due to the non-interacting neutrals present in the plasma. The contrasting effects of the He and He-air plasma could be due to their differential effects on protein and RNA. This is possible if the plasma treatment causes degradation/deformation of structural proteins of the virus particles releasing RNA. While He-air Plasma treatment as explained earlier in Figure 2, induces more $\mathrm{OH}$ radicals which can interfere with the RNA structure causing the reduction in abundance of the gene. However, to have a clear understanding e we have quantified the role of different radicals produced in the $\mathrm{He}$ and $\mathrm{He}-$ Air plasma.

To verify the role of the RONS in the deactivation of the spike protein as well as the on the gene abundance, we quantified the radicals $\mathrm{OH}, \mathrm{H}_{2} \mathrm{O}_{2}$ and Nitrates using different assays (Table 1). The striking feature we observed in this work is that with He Plasma we had a high concentration of $\mathrm{H}_{2} \mathrm{O}_{2}$ for a treatment time of $1 \mathrm{~min}$, which decreases nearly 5 times when treated for $2 \mathrm{~min}$. This change is reflected in the increase of $\mathrm{OH}$ radicals ( $8 \mu \mathrm{M}$ to $100 \mu \mathrm{M}$ in $2 \mathrm{~min}$ ) which could be due to the dissociation of the $\mathrm{H}_{2} \mathrm{O}_{2}$ to $\mathrm{OH}$ radicals upon interacting with higher energy electrons obtained from the He Plasma ${ }^{38}$. In the case of He-Air plasma, we observe that the concentration of $\mathrm{H}_{2} \mathrm{O}_{2}$ increases from $28.6 \mu \mathrm{M}$ to 37.2 $\mu \mathrm{M}$ in $2 \mathrm{~min}$. The concentration of nitrate remains almost the same for He-Air plasma whereas the nitrite concentration increases for both $\mathrm{He}$ and He-Air plasma with the treatment time. The presence of nitrite and its increasing concentration with treatment time may be responsible for the interaction of these nitrites with the spike protein for further reactions. Such conversion of nitrites to nitrogen is reported for several amino acids and proteins ${ }^{39}$. 
Table 1

Quantification of various active oxygen and nitrogen species in the He plasma and $\mathrm{He}$ Air plasma

\begin{tabular}{|lllll|}
\hline Samples/Time & $\begin{array}{l}\text { Hydroxyl radicals } \\
(\mu \mathrm{M})\end{array}$ & $\begin{array}{l}\mathrm{H}_{2} \mathrm{O}_{2} \\
(\mu \mathrm{M})\end{array}$ & $\begin{array}{l}\text { Nitrate } \\
(\mu \mathrm{M})\end{array}$ & $\begin{array}{l}\text { Nitrite } \\
(\mu \mathrm{M})\end{array}$ \\
\hline He Plasma 1 min & $7.29 \pm 0.23$ & $29.4 \pm 0.45$ & $21 \pm 0.53$ & $54.2 \pm 0.9$ \\
\hline He Plasma 2 min & $100 \pm 1.2$ & $6.1 \pm 0.06$ & $61.5 \pm 1.2$ & $97.4 \pm 1.56$ \\
\hline He-Air Plasma 1 min & $1.56 \pm 0.05$ & $28.6 \pm 0.57$ & $10.1 \pm 0.18$ & $22.1 \pm 0.29$ \\
\hline He-Air Plasma 2 min & $3.11 \pm 0.08$ & $37.2 \pm 0.53$ & $10.6 \pm 0.24$ & $39.6 \pm 0.65$ \\
\hline
\end{tabular}

From our work we conclude that the spike protein deactivation is possibly due to the amount of hydrogen peroxide produced in the sample. Such reports on deactivation of proteins in the presence of $\mathrm{H}_{2} \mathrm{O}_{2}$ have been earlier reported ${ }^{40,41}$. We also see differential peroxide production in different plasma such as $\mathrm{He}$ and He-Air Plasma which could lead to the protein deactivation (Figure 3) as well as the change in the gene abundance (Figure 4).

\section{Conclusions}

In this study we have conducted a systematic evaluation of CAP plasma-based decontamination of SARS-Cov-2 virus. We observed complete inactivation of the spike protein in the presence of the He-air mixed feed gas plasma compared to the He-plasma. DNPH assay suggests the carbonyl modification of the spike protein due to the reactive oxygen species (ROS) induced in the plasma which inhibits the binding with hACE2 protein. On the other hand, direct exposure of the extracted RNA to the He and He-air plasma has shown evidence on modification on the gene abundance in the RT-PCR experiment. We have shown the hydrogen peroxide from the CAP mediates the deactivation of the spike protein and influences the gene abundance. Additionally, CAP plasma disinfection is definitely a better alternative compared to the current chemical-based decontamination which causes several environmental hazards and can be utilized for medical devices, surfaces and in air purification. Hence, cold atmospheric pressure plasma with optimal tuning of the reactive species could be a synergistic method to be used for SARS-CoV-2 virus inactivation.

\section{Declarations}

Written informed consents were taken for using the RNA samples. All the experiments were performed in an Indian Council of Medical Association (ICMR) approved biosafety level 2 (BSL-2) Covid-19 testing and research laboratory and by following the ethical and biosafety guidelines approved by IASST.

\section{Acknowledgment:}


Authors would like to thank National Health Mission, Govt. of Assam, Gauhati Medical College and Hospital, and Covid Testing and Research Laboratory, IASST, Guwahati for providing infrastructure facility and technical support. Authors thank SAIF, IASST for the facilities. Authors KS and HB thank the IASST inhouse grant. Author RRK thanks DST, Govt. of India for the support under DST-INSPIRE Fellowship Scheme. Author MK, PK thanks IASST for the research fellowship. The authors thank SAIF, IASST for the analytical facilities.

\section{References}

1. Chen, C. Y. et al. Structure of the SARS Coronavirus Nucleocapsid Protein RNA-binding Dimerization Domain Suggests a Mechanism for Helical Packaging of Viral RNA. J. Mol. Biol. 368, 1075-1086 (2007).

2. Yang, J. et al. Molecular interaction and inhibition of SARS-CoV-2 binding to the ACE2 receptor. Nat. Commun. 11, 4541 (2020).

3. Sakkiah, S. et al. Elucidating Interactions Between SARS-CoV-2 Trimeric Spike Protein and ACE2 Using Homology Modeling and Molecular Dynamics Simulations. Front. Chem. 8, 622632 (2021).

4. Morawska, L. et al. How can airborne transmission of COVID-19 indoors be minimised? Environ. Int. 142,105832 (2020).

5. Lin, A. et al. Non-Thermal Plasma as a Unique Delivery System of Short-Lived Reactive Oxygen and Nitrogen Species for Immunogenic Cell Death in Melanoma Cells. Adv. Sci. 6, 1802062 (2019).

6. Moreau, M., Orange, N. \& Feuilloley, M. G. J. Non-thermal plasma technologies: New tools for biodecontamination. Biotechnol. Adv. 26, 610-617 (2008).

7. Filipić, A., Gutierrez-Aguirre, I., Primc, G., Mozetič, M. \& Dobnik, D. Cold Plasma, a New Hope in the Field of Virus Inactivation. Trends Biotechnol. 38, 1278-1291 (2020).

8. Bernhardt, T. et al. Plasma Medicine: Applications of Cold Atmospheric Pressure Plasma in Dermatology. Oxid. Med. Cell. Longev. 2019, 3873928 (2019).

9. Lee, M. H. et al. Removal and sterilization of biofilms and planktonic bacteria by microwave-induced argon plasma at atmospheric pressure. New J. Phys. 11, 115022 (2009).

10. Zashev, M., Donchev, D., Ivanov, I. \& Gornev, R. Efficacy of Plasma ONE apparatus for disinfection of S. aureus, P. aeruginosa and E. coli bacteria from the solid surface. J. Theor. Appl. Phys. 14, 41-49 (2020).

11. Hojnik, N. et al. Effective Fungal Spore Inactivation with an Environmentally Friendly Approach Based on Atmospheric Pressure Air Plasma. Environ. Sci. Technol. 53, 1893-1904 (2019).

12. Choi, S. et al. Structural and functional analysis of lysozyme after treatment with dielectric barrier discharge plasma and atmospheric pressure plasma jet /631/45 /631/57 /101/82 /145 article. Sci. Rep. 7, 1027 (2017).

13. Attri, P. et al. Influence of reactive species on the modification of biomolecules generated from the soft plasma. Sci. Rep. 5, 8221 (2015). 
14. Attri, P. et al. Structural modification of NADPH oxidase activator (Noxa 1) by oxidative stress: An experimental and computational study. Int. J. Biol. Macromol. 163, 2405-2414 (2020).

15. Lackmann, J. W. et al. A dielectric barrier discharge terminally inactivates RNase A by oxidizing sulfur-containing amino acids and breaking structural disulfide bonds. J. Phys. D. Appl. Phys. 48, 494003 (2015).

16. Guo, L. et al. Plasma-activated water: An alternative disinfectant for $S$ protein inactivation to prevent SARS-CoV-2 infection. Chem. Eng. J. 421, 127742 (2021).

17. Chen, Z., Garcia, G., Arumugaswami, V. \& Wirz, R. E. Cold atmospheric plasma for SARS-CoV-2 inactivation. Phys. Fluids 32, 111702 (2020).

18. Patra, V. K., Byrne, S. N. \& Wolf, P. The skin microbiome: Is it affected by UV-induced immune suppression? Front. Microbiol. 7, 1235 (2016).

19. Khanikar, R. R., Boruah, P. J. \& Bailung, H. Development and optical characterization of an atmospheric pressure non-thermal plasma jet for superhydrophobic surface fabrication. Plasma Res. Express 2, 045002 (2020).

20. Levine, R. L., Williams, J. A., Stadtman, E. R. \& Shacter, E. Carbonyl Assays for Determination of Oxidatively Modified Proteins. Methods Enzymol. 233, 346-357 (1994).

21. Shen, S., Tan, T. H. P. \& Tan, Y.-J. Expression, Glycosylation, and Modification of the Spike (S) Glycoprotein of SARS CoV. in Methods in Molecular Biology (ed. Sugrue, R. J.) 379, 127-135 (Humana Press, 2007).

22. Du, L. et al. The spike protein of SARS-CoV - A target for vaccine and therapeutic development. Nat. Rev. Microbiol. 7, 226-236 (2009).

23. Xiao, X. \& Dimitrov, D. S. The SARS-CoV S glycoprotein. Cell. Mol. Life Sci. 61, 2428-2430 (2004).

24. Nalla, A. K. et al. Comparative performance of SARS-CoV-2 detection assays using seven different primer-probe sets and one assay kit. J. Clin. Microbiol. 58, e00557-20 (2020).

25. Schmittgen, T. D. \& Livak, K. J. Analyzing real-time PCR data by the comparative CT method. Nat. Protoc. 3, 1101-1108 (2008).

26. Kramida, A., Ralchenko, Y., Reader, J. \& NIST ASD Team. NIST Atomic Spectra Database (version 5.8), [Online] https://physics.nist.gov/PhysRefData/ASD/lines_form.html (accessed Jun 6, 2021).

27. Pearse, R. W. B. \& Gaydon, A. G. The Identification of Molecular Spectra. Second Ed., (Chapman \& Hall Ltd., 1950).

28. Luque, J. M. \& Crosley, D. R. LIFBASE: Database and Spectral Simulation Program (Version 2.1). SRI Int. Rep. MP 99, (1999).

29. Laux, C. O. Radiation and nonequilibrium collisional-radiative models. Physico-Chemical Model. High Enthalpy Plasma Flows (Rhode-Saint-Genèse, Belgium, 4-7 June 2002) ed D Fletcher al (von Karman Inst. Spec. Course) www.specair-radiation.net (2002).

30. Laux, C. O., Spence, T. G., Kruger, C. H. \& Zare, R. N. Optical diagnostics of atmospheric pressure air plasmas. Plasma Sources Sci. Technol. 12, 125-138 (2003). 
31. Hofmann, S., Van Gessel, A. F. H., Verreycken, T. \& Bruggeman, P. Power dissipation, gas temperatures and electron densities of cold atmospheric pressure helium and argon RF plasma jets. Plasma Sources Sci. Technol. 20, 065010 (2011).

32. Grimsrud, P. A., Xie, H., Griffin, T. J. \& Bernlohr, D. A. Oxidative stress and covalent modification of protein with bioactive aldehydes. J. Biol. Chem. 283, 21837-21841 (2008).

33. Stadtman, E. R. Role of Oxidant Species in Aging. Curr. Med. Chem. 11, 1105-1112 (2012).

34. Ke, Z. \& Huang, Q. Inactivation and heme degradation of horseradish peroxidase induced by discharge plasma. Plasma Process. Polym. 10, 731-739 (2013).

35. Park, J. H. et al. Variation in structure of proteins by adjusting reactive oxygen and nitrogen species generated from dielectric barrier discharge jet. Sci. Rep. 6, 35883 (2016).

36. Huang, Y., Yang, C., Xu, X. feng, Xu, W. \& Liu, S. wen. Structural and functional properties of SARSCoV-2 spike protein: potential antivirus drug development for COVID-19. Acta Pharmacol. Sin. 41, 1141-1149 (2020).

37. Zhang, $\mathrm{X}$. et al. The $\mathrm{N}$ gene of SARS-CoV-2 was the main positive component in repositive samples from a cohort of COVID-19 patients in Wuhan, China. Clin. Chim. Acta 511, 291-297 (2020).

38. Lyu, L., Zhang, L., He, G., He, H. \& Hu, C. Selective H2O2 conversion to hydroxyl radicals in the electron-rich area of hydroxylated C-g-C3N4/CuCo-Al2O3. J. Mater. Chem. A 5, 7153-7164 (2017).

39. Kato, T. \& Kikugawa, K. Proteins and amino acids as scavengers of nitrite: inhibitory effect on the formation of nitrosodimethylamine and diazoquinone. Food Chem. Toxicol. 30, 617-626 (1992).

40. Denu, J. M. \& Tanner, K. G. Specific and reversible inactivation of protein tyrosine phosphatases by hydrogen peroxide: Evidence for a sulfenic acid intermediate and implications for redox regulation. Biochemistry 37, 5633-5642 (1998).

41. Drozdz, R.; Naskalski, J.W. Inactivation and denaturation of some proteins by enzyme system: myeloperoxidase, chloride and hydrogen peroxide. Folia Histochem Cytobiol. 31, 71-75 (1993).

\section{Figures}




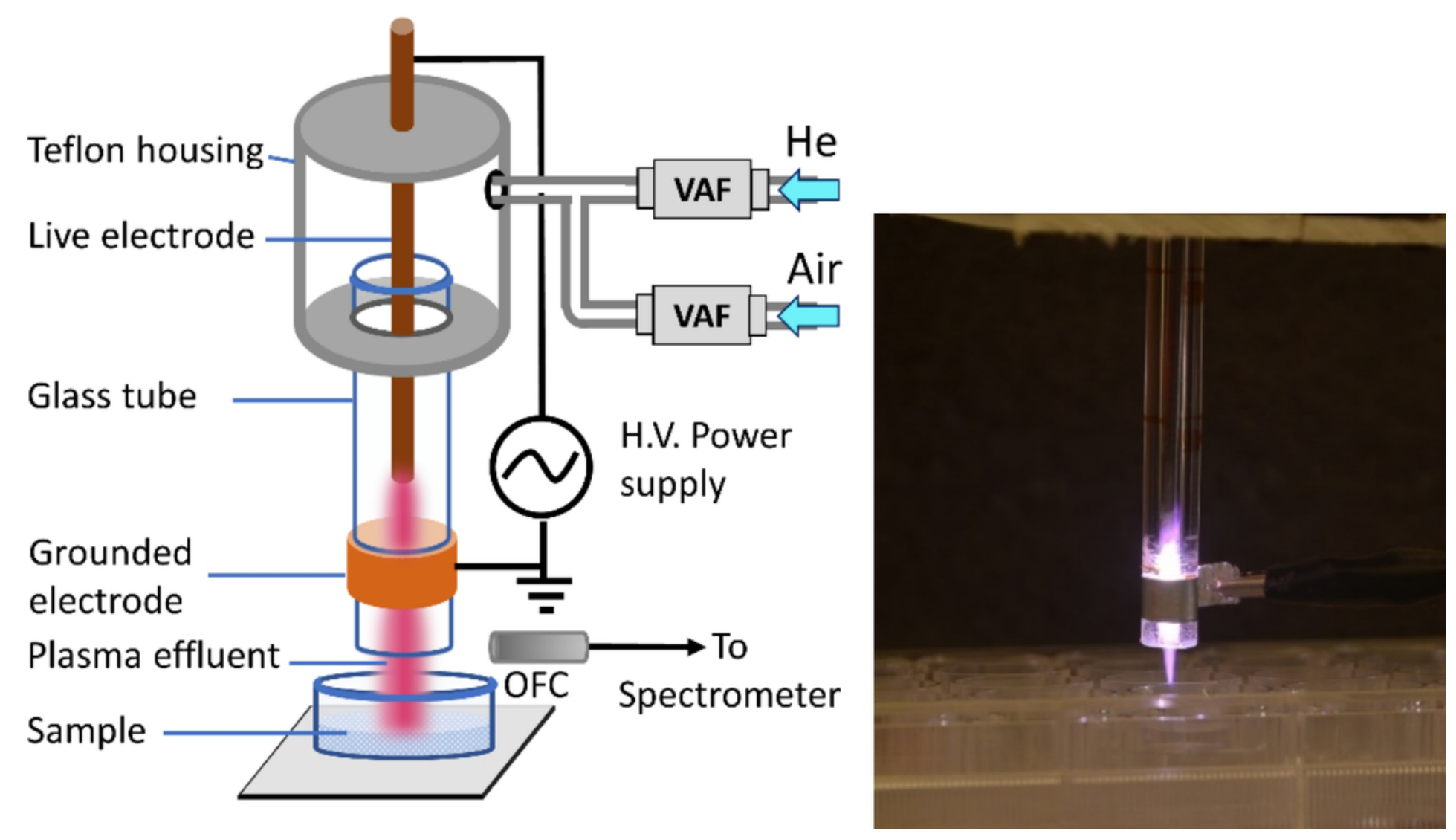

Figure 1

(a). Schematic diagram of the experimental set up. VAF: variable area flowmeter, OFC: optical fiber cable

(b) Photograph of the CAP plasma plume coming out of the glass tube. 

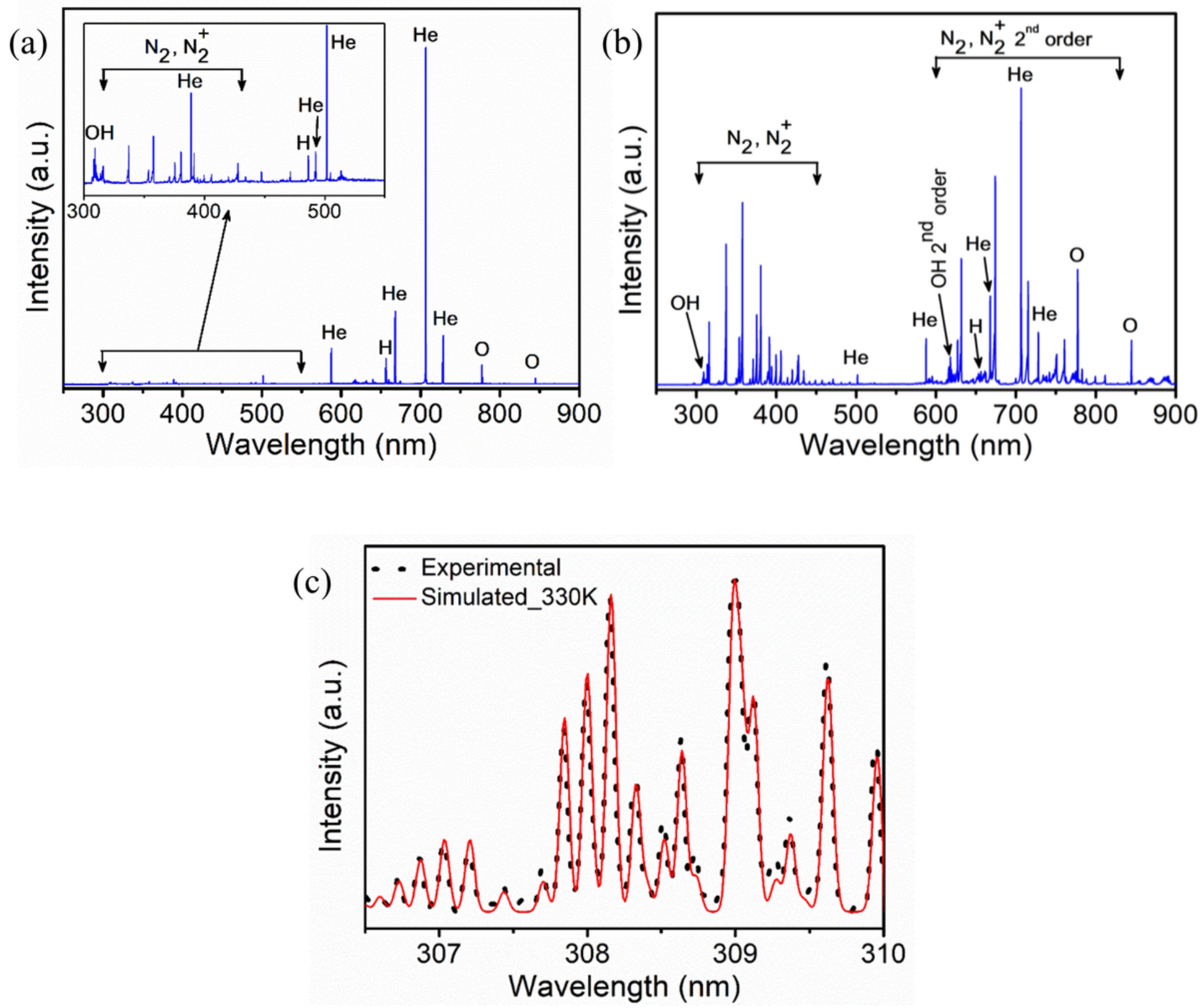

Figure 2

Emission spectra of (a) He plasma jet (inset: spectrum 300-550 nm is enlarged to show the reactive species), (b) He-air plasma jet and (c) the best fit between experimental and simulated spectra of $\mathrm{OH}$ for gas temperature measurement. 

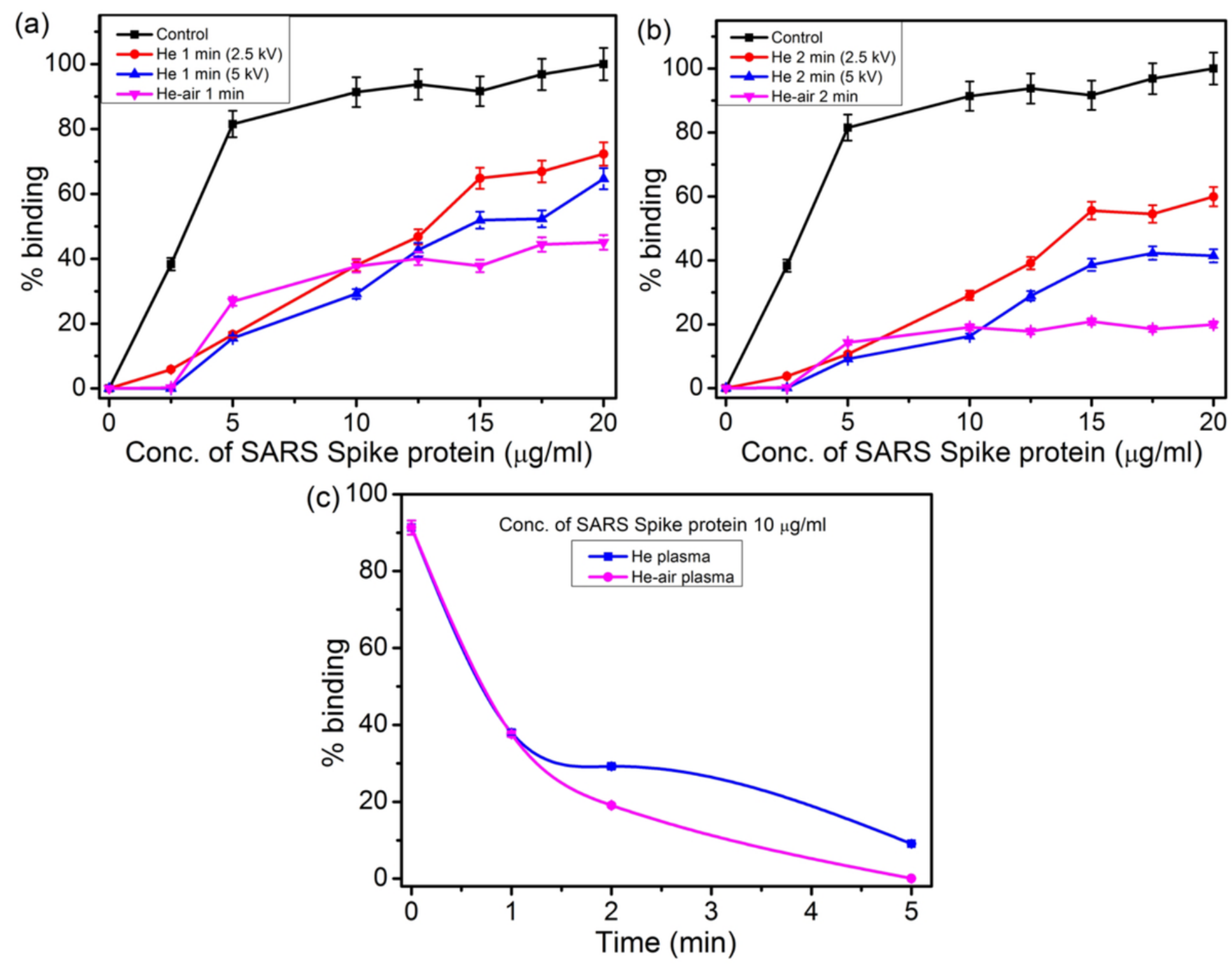

Figure 3

Effect of plasma treatment on binding of SARS-CoV-2 spike protein with ACE2 receptor (a) time $=1 \mathrm{~min}$ and (b) time $=2 \mathrm{~min}(\mathrm{c})$ Spike protein $(10 \mu \mathrm{g} / \mathrm{ml})$ binding to ACE2 after plasma treatment for different time intervals. 


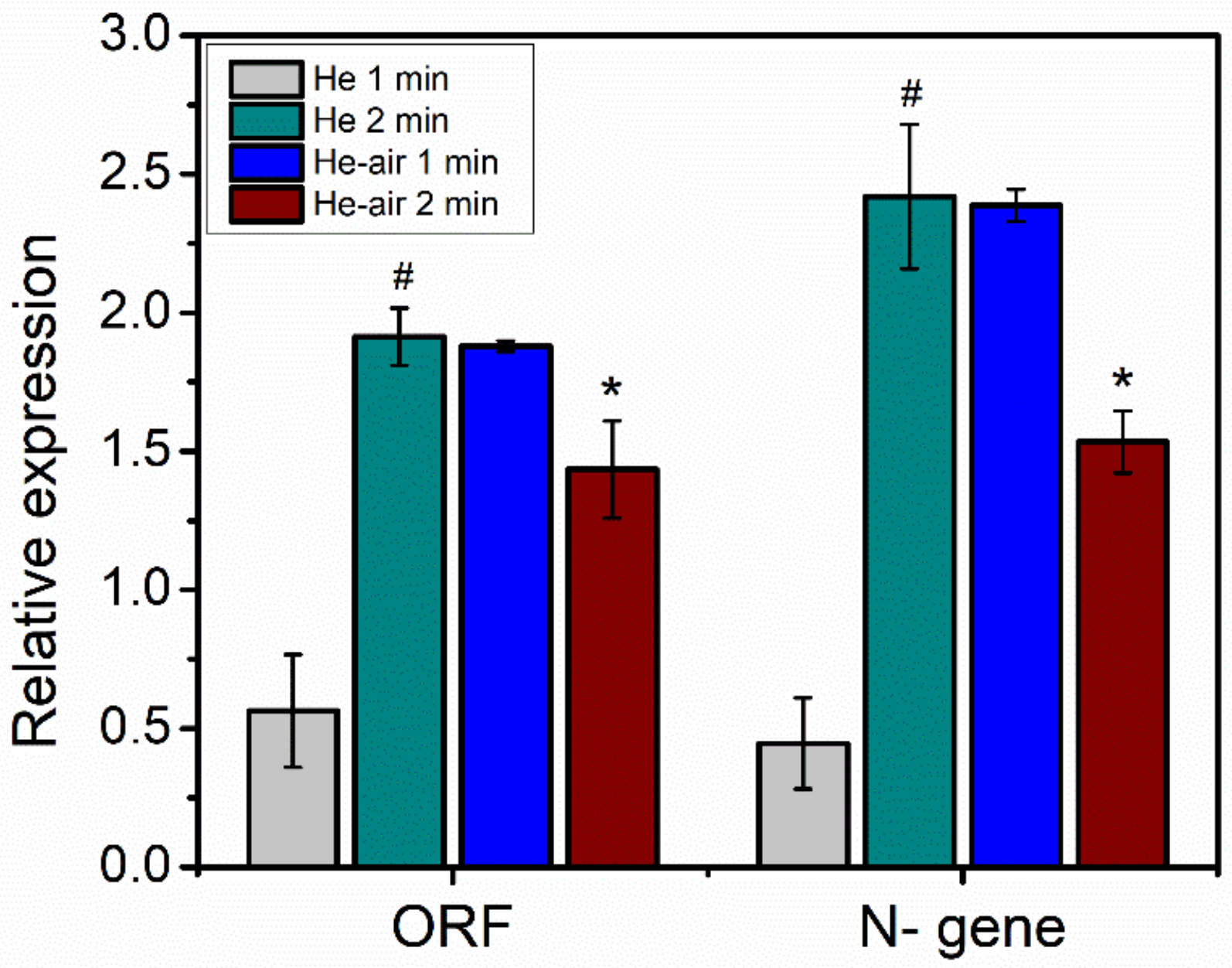

Figure 4

Relative Abundance of ORF-gene and N-gene upon plasma treatment (*is significant compared to \#).

\section{Supplementary Files}

This is a list of supplementary files associated with this preprint. Click to download.

- Graphicalabstract.png 